\title{
Analisis Kelayakan Usaha Pembuatan Gula Merah Di Kelurahan Kassa Kecamatan Batulappa Kabupaten Pinrang
}

\author{
Feasibility Analysis Of Brown Sugar Making Business In Kelurahan Kasa, Batulappa \\ District, Pinrang Regency
}

\author{
Idham Anggi Syamita $^{1 *}$, Nurhapsah ${ }^{1}$ Nurhaedah $^{1}$ \\ "Email: bongkaridham54791@gmail.com \\ ${ }^{1}$ Fakultas Pertanian, Peternakan dan Perikanan Universitas Muhammadiyah Parepare
}

Diterima: 25 September 2021 / Disetujui: 24 Desember 2021

\begin{abstract}
ABSTRAK
Penelitian ini dilaksanakan di Kelurahan Kassa Kecamatan Batulappa Kabupaten Pinrang dari bulan Agustus sampai bulan September 2019. Penelitian ini bertujuan untuk mengetahui faktor-faktor produksi ( pohon aren, harga gula merah, biaya produksi, jumlah pohon, jumlah produksi). Pada pendapatan pengrajin gulan aren di Kelurahan Kassa Kecamatan Batulappa Kabupaten Pinrang. Jenis data yang digunakan adalah analisis regresi berganda. Hasil penelitian ini kemudian diolah menggunakan rumus analisis Pendapatan. Variabel yang digunakan dalam penelitian ini ada lima yaitu harga gula aren, biaya, volume produksi, tenaga kerja, jumlah pohon. Hasil penelitian menunjukan variabel harga gula aren dan jumlah produksi berpengaruh nyata terhadap pendapatan sedangkan biaya, tenaga kerja dan jumlah pohon tidak berpengaruh nyata terhadap pendapatan pengrajin gula merah. Hasil uji F disimpulkan bahwa variabel bebas sangat berpengaruh terhadap pendapatan pengrajin gula merah. Hasil uji R square menunjukan bahwa 98,9\% variabel pendapatan pengrajin gula merah dapat dijelaskan oleh variabel jumlah pohon aren, jumlah produksi, tenaga kerja, dan harga. Sedangkan 1,1\% dipengaruhi oleh variabel lain yang tidak di ukur dalam penelitian
\end{abstract}

Kata Kunci: Faktor Produksi, Pendapatan

\section{ABSTRACT}

This research was conducted in Kassa Village, Batulappa District, Pinrang Regency from August to September 2019. This study aims to determine the factors of production (palm trees, brown sugar prices, production costs, number of trees, number of production). On the income of palm sugar craftsmen in Kassa Village, Batulappa District, Pinrang Regency. The type of data used is multiple regression analysis. The results of this study were then processed using the analysis formula income. There are five variables used in this research, namely palm sugar price, cost, production volume, labor, number of trees. The results showed that the variable palm sugar price and the amount of production had a significant effect on income, while the cost, labor and number of trees had no significant effect on the income of the brown sugar craftsmen. The results of the F test concluded that the independent variable greatly influenced the income of the brown sugar craftsmen. The results of the $R$ square test show that $98.9 \%$ of the income variable of the brown sugar craftsmen can be explained by the variables of the number of palm trees, the amount of production, the labor, and the price. Meanwhile, $1.1 \%$ is influenced by other variables that are not measured in the study.

Keywords: Production Factors, Income

(a) () This work is licensed under Creative Commons Attribution License 4.0 CC-BY International license

\section{A. PENDAHULUAN}

Tanaman aren (Arenga Pinnata

Merr) merupakan tanaman yang menghasilkan bahan - bahan industri

karena hampir semua bagian tanaman ini dapat dimanfaatkan dan memiliki nilai 
ekonomi.Tanaman aren sebagian besar diusahakan oleh petani dan belum diusahakan dalam skala besar, karena pengelolaan tanaman belum menerapkan teknik budidaya yang baik menyebabkan produktivitas pertanaman rendah.

Pendapatan yang diperoleh pengrajin gula merah belum dapat memperbaiki kondisi sosial pengrajin gula merah sehingga tidak dapat digunakan untuk tabungan dan di investasi.Selain itu pengrajin gula merah tidak memiliki waktu luang untuk diri mereka sendiri karena proses pembuatan gula merah yang memakan waktu lama dan harus dilakukan secara tradisional dengan alat sederhana dan bantuan tenaga manusia.

Salah satu kelurahan yang melakukan produksi gula merah di Kabupaten Pinrang yaitu Kelurahan Kassa yang terletak di kecamatan Batulappa Kabupaten Pinrang.Kelurahan Kassa telah memproduksi gula merah rata rata 3.600 $\mathrm{kg}$ perbulan dengan harga $\mathrm{Rp}$ 70.000/Kg.kemudian untuk proses penjualannya kadang di pesan langsung oleh masyarakat dan kadang di bawa ke pasar untuk di jual.

Masyarakat kelurahan Kassa telah memproduksi gula merah dalam kurun waktu yang cukup lama, namun ternyata belum terlihat adanya tanda-tanda mengenai kwalitas hidup yang lebih baik sedangkan rata-rata kerja yang lama sekitar 14 jam dari proses penyadapan nira hingga proses pemasakan gulaaren selesai.

Melihat kondisi sosial di Kelurahan Kassa ini peneliti bermaksud untuk mengadakan penelitian masyarakat Kelurahan Kassa yang memproduksi gula merah sebagai mata pencaharian utama karena mudahnya akses.Menurut observasi peneliti, di Kelurahan Kassa sendiri kesejahteraan pengrajin gula merah belum tampak jelas.Industri rumah tangga gula merah menjadi penyangga ekonomi masyarakat Desa kelurahan Kassa, dan sampai sekarang masih menjadi pekerjaan utama petani gula tanpa ada produk lain yang dihasilkan dari air nira.

\section{B. METODE PENELITIAN}

\section{Waktu dan Tempat}

Penelitian ini dilakukan selama 2 bulan yaitu mulai bulan Agustu sampai bulan September 2019 Di Kelurahan Kassa Kecamatan Batulappa Kabupaten Pinrang.

\section{Populasi dan Sampel}

Populasi adalah wilayah generalisasi yang terdiri atas objek/subjek yang mempunyai kuantitas dan karakteristik tertentu yang ditetapkan oleh 
peneliti untuk dipelajari dan kemudian ditarik kesimpulannya.Populasi yang menjadi objek penelitian ini adalah pengrajin gula merah yang ada di Kelurahan Kassa Kecamatan Batulappa Kabupaten Pinrang yang berjumlah 53 orang. Penentuan jumlah sampel, menggunakan formulasi Slovin (Umar, 2004):

$$
\mathrm{n}=\frac{N}{1+N e^{2}}
$$

Keterangan:

$\mathrm{n}$ : ukuran sampel

$\mathrm{N}$ : ukuran populasi

e : presentase kelonggaran ketelitian sebesar 15\%.

Berdasarkan rumus tersebut maka dapat ditentukkan jumlah sampel sebagai berikut:

$$
\begin{gathered}
\mathrm{n}=\frac{\mathrm{N}}{1+\mathrm{Ne}^{2}} \\
=\frac{53}{1+53(15 \%)^{2}} \\
=\frac{53}{1+53(0.15)^{2}} \\
=\frac{53}{2.19}=24
\end{gathered}
$$

Mendasarkan pada populasi pengrajin gula aren sebanyak 53 orang, maka diperoleh jumlah sampel sebanyak pengrajin gula merah. Sampel tersebut terdiri dari 24 orang.

\section{Teknik Pengumpulan Data}

a. Observasi yaitu pengumpulan data yang dilakukan dengan cara melakukan pengamatan langsung terhadap kegiatan usaha pengolahan gula merah di Kelurahan Kassa Batulappa Kabupaten Pinrang.

b. Wawancara merupakan bagian dari teknik komunikasi dimana pencari atau mengadakan tanya jawab dengan narasumber untuk menggali data yang diperlukan.Dengan wawancara ini keterangan dan informasi tentang data-data yang berhubungan dengan penelitian dapat diperoleh melalui wawancara dengan pengusaha, pegawai pemerintah terkait dan lain-lain. Wawancara dilakukan untuk memperoleh data dari pengrajin gula merah di Kelurahan Kassa Batulappa Kabupaten Pinrang maupun dari instansi-instansiterkait.

c. Kuesioner, yaitu pengumpulan data dengan menggunakan pertanyaan sebagai pedoman dalam melakukan wawancara dengan responden.

d. Dokumentasi adalah cara untuk memperoleh data atau informasi tentang hal-hal yang ada kaitannya dengan penelitian, dengan cara melihat kembali sumber tertulisyang lalu baik berupa angka atau keterangan seperti buku-buku, majalah, dokumen,peraturanperaturan, notulen rapat, catatan 
harian dan sebagainya (Arikunto, 2006).

\section{Metode Analisis Data}

Soekartawi (1995) menyatakan total biaya adalah penjumlahan biaya variabel dengan biaya tetap secara matematis, adapun metode yang di gunakan dalam analisis pengrajin gula merah adalah sebagai berikut :

\section{$\mathbf{T C}=\mathbf{F C}+\mathrm{VC}$}

Keterangan:

$\mathrm{TC}=$ Total Cost (Total biaya dari pengrajin gula merah lada Rp)

$\mathrm{FC}=$ Fixed Cost (Total biaya dari pengrajin gula merah $\mathrm{Rp}$ )

$\mathrm{VC}=$ Variabel Coat (Total biaya variabel pengrajin gula merah $\mathrm{Rp}$ )

Menurut Soekartawi (2006)

penerimaan usahatani adalah perkalian antara produksi dengan harga jual, biaya usahatani adalah semua pengeluaran yang dipergunakan dalam suatu usahatani, sedangkan pendapatan usaha tani adalah selisih antara penerimaan dan pengeluaran. Pernyataan ini secara matematis dapat dituliskan sebagai berikut:

$$
\mathbf{T R}=\mathbf{Q . P}
$$

Keterangan:

$\mathrm{TR}($ Total Revenue $=$ penerimaan total petani (Rp)

$\mathrm{Q}$ (quantity) $\quad=$ jumlah produk yang $\mathrm{di}$ hasilkan (Kg, Ton)

$\mathrm{P}$ price

$=$ harga jual produk yang di hasilkan ( $\mathrm{Rp} / \mathrm{Kg}, \mathrm{Rp} / \mathrm{Ton})$

Soekartawi (1995) menyatakan pendapatan usahatani adalah selisih antara penerimaan (TR) dan semua biaya (TC), dimana penerimaan usahatani adalah perkalian antara produksi dan harga jual, sedangkan biaya adalah semua pengeluaran yandigunakan dalam suatu usahatani. Jadi rumus pendapatan dapat dituliskan sebagai berikut:

$$
\pi=\mathrm{TR}-\mathrm{TC}
$$

Keterangan:

$\pi \quad=$ Pendapatan petani lada (Rp)

TR Total Revenue $\quad=$ penerimaan pengrajin Gula merah (Rp)

$\mathrm{TC}$ Total Cost $\quad=$ total biaya produksi Gula merah (Rp)

Pendapatan

$$
\Pi=\mathrm{TR}-\mathrm{TC}
$$

Keterangan ;

$\Pi=$ Pendapatan

$\mathrm{TR}=$ Total Penerimaan

$\mathrm{TC}=$ Total Biaya

\section{HASIL DAN PEMBAHASAN}

Hasil Analisis Pendapatan Pengrajin Gula Merah di Kelurahan Kassa Kecamatan Batulappa Kabupaten Pinrang

\section{Biaya tetap}

Biaya tetap merupakan biaya yang di keluarkan dalam besaran yang tetap atau stabil.Biaya tetap ini keberadaannya tidak di pengaruhi oleh adanya perubahan jumlah atau aktivitas produksi pada tingkat tertentu. Biaya tetap yang di maksud adalah biaya yang biaya penyusutan alat-alat yang di gunakan saat memprosuksi gula merah atau biaya yang besar kecilnya tidak tergantung pada besar kecilnya produksi,Biaya tetap dalam 
penelitian ini adalah pajak dan penyusutan alat alat produksi yaitu wajan,parang,cetakan,baskom dan jergen.

Tabel.1. Deskripsi Biaya Tetap Yang

Digunakan Oleh Responden Usaha Pembuatan Gula Merah

\begin{tabular}{clcc}
\hline No & $\begin{array}{c}\text { Jenis Biaya } \\
\text { Tetap }\end{array}$ & $\begin{array}{c}\text { Jumlah } \\
(\mathbf{R p})\end{array}$ & $\begin{array}{c}\text { Rata- } \\
\text { rata } \\
(\mathbf{R p})\end{array}$ \\
\hline 1 & Pajak Lahan & 1.030 .000 & 42.916 \\
2 & Penyusutan Alat & 2.130 .600 & 88.775 \\
\hline & Jumlah & $\mathbf{2 . 2 3 3 . 6 0 0}$ & $\mathbf{1 3 1 . 6 9 1}$ \\
\hline
\end{tabular}

Tabel 1. mendeskripsikan bahwa ada 2 biaya tetap yang dikeluarkan oleh setiap responden adalah pajak dan penyusutan peralatan dimana biaya pajak yang dikeluarkan petani sebesar $\mathrm{Rp}$ 1.030.000 per satu tahun. Sedangkan biaya penyusutan peralatan yang dikeluarkan petani sebesar Rp.2.130.600., maka total biaya tetap yang dikeluarkan oleh petani responden sebesar Rp.2.233.600.

Berdasarkan pendapat yang dikemukakan oleh Muhammad(2004) bahwa biaya tetap yang dimaksud dalam penelitian ini adalah biaya yang tidak habis digunakan dalam satu kali proses produksi tetapi hanya mengalami penyusutan atau disebut sebagai biaya investasi seperti pengadaan peralatan untuk menunjang keberlanjutan usaha tani lada. Untuk mengeathui besarnya penyusutan dari masing-masing peralatan yang digunakan maka akan dihitung nilai penysutan yang habis dalam satu produksi.

\section{Biaya Variabel}

Biaya variabel ( variabel cost, disingkat VC) ialah biaya yang jumlahnya berubah-ubah sesuai dengan (tergantung dari) besar kecilnya jumlah produksi. Misalnya biaya bahan-bahan, upah buruh harian (Gilarso 1993). Di sisi lain biaya tidak tetap atau biaya variabel biasanya di definisikan sebagai biaya yang besar kecilnya dipengaruhi oleh produksi yang di peroleh. Yang termasuk dalam biaya variabel meliputi benih, pupuk, obat-obatan, tenaga kerja. Disebut pula biaya operasi, artinya manajer selalu mengatur, mengeluarkan sepanjang waktu produksi. Biaya ini selalu berubah tergantung kepada besar kecilnya produksi.

Tabel 2. Deskripsi Biaya Variabel Yang Digunakan Oleh Responden Usaha Pembuatan Gula Merah

\begin{tabular}{cccc}
\hline No & $\begin{array}{c}\text { Jenis Biaya } \\
\text { Variabel }\end{array}$ & $\begin{array}{c}\text { Jumlah } \\
(\mathbf{R p})\end{array}$ & $\begin{array}{c}\text { Rata-rata } \\
(\mathbf{R p})\end{array}$ \\
\hline 1 & Tenaga kerja & 1.240 .000 & 51.666 \\
\hline
\end{tabular}

Tabel 2. mendiskripsikan biaya variabel yang dikeluarkan oleh 24 orang pelaku usaha responden di Kelurahan Kassa Kecamatan Batulappa Kabupaten Pinrang adalah Rp. 1.240.00 atau dengan rata-rata sebesar $\mathrm{Rp} 51.666$ biaya ini hanya pembelian Tenaga Kerja, hal ini disebabkan bahan utama yaitu air nira 
pelaku usaha sudah mempunyai masing masing pohon.

\section{Total Biaya Produksi}

Total biaya adalah biaya yang dikeluarkan selama proses produksi, besarnya biaya yang dikeluarkan untuk memproduksi sesuatu menentukan harga pokok dari produk yang dihasilkan. Biaya-biaya yang dimaksud adalah biaya yang diperhitungkan sehubungan dengan penelitian ini, yaitu biaya tetap dan biaya variabel yang dikeluarkan yang tidak langsung mempengaruhi besarnya produk yang dihasilkan. Sedangkan biaya variabel adalah biaya yang dikeluarkan yang mempengaruhi secara langsung jumlah produk yang dihasilkan.

Tabel 3. Rata-rata Total Biaya Produksi yang Digunakan Oleh Usaha gula Merah

Di Kelurahan Kassa Kecamatan Batulappa Kabupaten Pinrang

\begin{tabular}{clcc}
\hline No & $\begin{array}{c}\text { Total Biaya } \\
\text { Produksi }\end{array}$ & $\begin{array}{c}\text { Jumlah } \\
(\mathbf{R p})\end{array}$ & $\begin{array}{c}\text { Rata- } \\
\text { rata } \\
(\mathbf{R p})\end{array}$ \\
\hline 1 & $\begin{array}{l}\text { Total Biaya } \\
\text { Tetap }\end{array}$ & 2.233 .600 & 106.122 \\
2 & $\begin{array}{l}\text { Total biaya } \\
\text { variable }\end{array}$ & 1.240 .000 & 51,666 \\
\hline & Jumlah & $\mathbf{3 . 4 7 3 . 6 0 0}$ & $\mathbf{1 5 7 . 7 8 8}$ \\
\hline
\end{tabular}

Tabel 3. menunjukan jumlah ratarata biaya yang dikeluarkan secara keseluruhan usaha responden di Kelurahan Kecamatan Batulappa Kabupaten Pinrang dengan biaya variabel Rp. 1.240 .000 dan biaya tetap Rp. 2.233.600 sama dengan Rp. 3.473 .600 dengan biaya rata-rata dikeluarkan usaha responden sebesar Rp. 157.788. Untuk mengetahuai total penerimaan/total reveniue (TR) di gunakan rumus sebagai berikut.

$$
\mathrm{TR}=\mathrm{Q} X \mathrm{P}
$$

Keterangan:

TR : Total Perimaan

Q : Total Produksi $(\mathrm{Kg})$

$\mathrm{P}$ : Harga Produk $(\mathrm{Rp} / \mathrm{Kg})$

Jadi penerimaan rata-rata perorang yang diperoleh para responden adalah sebagai berikut :

$$
\begin{gathered}
\mathrm{TR}=\mathrm{Q} \times \mathrm{P} \\
\mathrm{TR}=29.16 \mathrm{~kg} \times 62.083 \mathrm{Rp} / \mathrm{Kg} \\
=\mathrm{Rp} 1.810 .340 \mathrm{Rp} / \mathrm{Kg}
\end{gathered}
$$

Berdasarkan hasil diatas total penerimaan yang diperoleh petani responden yaitu dimana total produksi dikali dengan harga produk sehingga ratarata penerimaan di terimah responden perorang 1.328,4 kg Hal ini sesuai dengan pendapatan (Rahim 2004) bahwa penerimaa masing-masing petani responden secara terperinci berdasarkan luas lahan garapan. Pendapatan petani gula merah adalah pengurangan total penerimaan yang diperoleh dengan total biaya yang dikeluarkan dalam suatu produksi. Untuk mengetahui besar total pendapatan gula merah, maka digunakan rumus Sebagai berikut

$$
\pi=T R-T C
$$

Keterangan:

$\pi$ :Keutungan (Profit)

TR :Total Penrimaan( total revenue) 
TC :Total biaya ( total cost )

Jadi pendapatan rata-rata yang diperoleh petani responden adalah sebagai berikut :

$$
\begin{gathered}
\pi=\quad \text { TR-TC } \\
\pi=\operatorname{Rp~} 1.810 .340-\operatorname{Rp~} 157.788 \\
=\operatorname{Rp~} 1.652 .552
\end{gathered}
$$

Pendapatan rata-rata petani responden tiap periode sebesar $\mathrm{Rp}$ 1.652 .552

\section{Analisis Faktor Yang Mempengaruhi Pendapatan Pengrajin Gula Merah Di kelurahan Kassa Kecamatan Batulappa Kabupaten Pinrang}

\section{a. Harga}

Selain jumlah produksi, luas lahan tenaga kerja merupakan faktor yang tidak kalah pentingnya dalam mempengaruhi besar kecilnya pendapatan gula merah. Harga jual gula merah di tingkat petani bervariasi tergantung dengan saluran pemasaran yang di tempuh. Rata -rata harga gula merah dilokasi penelitian adalah Rp 66,42kg. sehingga gula merah dilokasi penelitian banyak di kembangkan karna harga jualnya yang begitu tinggi.

\section{b. Jumlah Produksi}

Sudarman (2003), menyatakan bahwa produksi sering di atau jasa untuk memenuhi kebutuhan manusia. Selain itu produksi juga merupakan proses kegiatan yang mengelolah bahan menta menjadi bahan yang bisa menambah nilai guna. Dalam memproduksi gula definisikan sebagai pecipta guna, dimana guna berati kemampuan barang aren dilakukan penyedapan terhadap beberapa jumlah pohon aren. Dalam hasil penelitian ini menujukkan bahwa jumlah pohon merah yang di sadap dalam satu hari satu malam adalah 5 pohon aren dari 24 responden yang memiliki jumlah tersebut. Produksi merupakan hasil akhir yang di preoleh dari suatu proses produksi. Produksi gula merah diperoleh dari kegiatan mengkombinasikan faktor-faktor produksi besar kecilnya produksi gula merah sangat mempengaruh terhadap pendapatan gula merah. Rata -rata produksi gula merah di lokasi penelitian hanya $20,14 \mathrm{~kg}$.

\section{c. Tenaga Kerja}

Syaful (2010) menyatakan bahwa tenaga kerja adalah setiap orang yang mampu melakukan pekerjaan guna menghasilkan barang atau jasa untuk memenuhi kebutuhan sendiri maupun untuk masyarakat. Hasl penelitian menunjukkan bahwa dominan jumlah tenaga kerja yang di gunakan responden adalah dalam memproduksi gula Merah adalah 1-4 orang.Tenaga kerja produktivitas tenaga kerja pada keluarga responden di Kelurahan Kassa Kecamatan 
Batulappa Kabupateng Pinrang adalah tenaga kerja yang berkerja um kerja umumnya dari kelurga responeden sediri. Tenaga kerja ini terdiri atas bapak,ibu dan anak. Dominan responden menyatakan bahwa umur tenaga kerja cukup berpengaruh dalam memproduksi gula Merah.Hal di karenakan semakin tua umur responeden maka semakin tinggi pengalamanya.

Djamali (2003) menyatakan bahwa tenaga kerja laki-laki dewasa di bedakan atas tenaga kerja laki-laki, perempuan dan anak-anak. Tenaga kerja manusia dapat mengerjakan semua jenis pekerjaan yang membutuhkan kemampuan otot yang tidak mampu di kerja oleh perempuan, jenis pekerjaan yang di lakukan oleh perempuan seperti memasak nira hingga menjadi gula dan memasukkanya dalam cetakan.sedangkan tenaga kerja untuk anak-anak memiliki waktu yang terbatas karena sebagian mereka adalah usia sekolah. Dari hasil penelitian tenaga kerja anka-anak seperti mengumpulkan kayu bakar.Faktor-faktor yang mempengaruhi pendapatan gula merah sebagaimana di ketahui bahwa penelitian ini dimaksudkan untuk mengetahui dan menganalisis seberapa besar pangaruh variabel harga, jumlah produksi ,Tenaga Kerja, luas lahan terhadap pendapatan gula merah di Kelurahan Kassa Kecamatan Batulappa Kabupateng Pinrang. Dalama penelitian ini metode yang di gunakan adalah analisis regresi berganda dengan bantuan program SPSS (statistical product and service solution).

\section{d. Jumlah pohon}

Jumlah pohon adalah tumbuhan yang batangnya berkayu dan bercabang. Batang pohon utama berdiri dan berukuran lebih besar di banding cabang cabangnya.untuk memperoleh hasil atau output pertanaian,salah satu factor yang menetukan adalah pohon atau bibit yang ada di lapangan atau yang di gunakan dalam menghasilkan produksi.Biaya produksi biasanya disamakan dengan biaya, makin tinggi modal suatu usaha menandakan bahwa besarnya lahan yang diusahakan pula oleh responden, namun itu semuanya tergantung jenis komoditi apa yang diusahakan oleh petani responden. Tanaman pohon aren salah satu komiditi unggulan di Kelurahan kassa.( Soekarno 2009).Penelitian ini skala menjadi penentu usaha yang didasarkan pada jumlah pohon aren yang ada di dalam perkebunan tiap-tiap responden. 


\section{KESIMPULAN DAN SARAN}

Hasil penelitian dan pembahasan dapat ditarik kesimpulan bahwa pendapatan pengrajin gula merah di kelurahan Kassa kecamatan Batulappa Kabupaten Pinrang adalah Rp1.652.522.. Untuk meningkatkan pendapatan produksi gula Merah di Kelurahan Kassa Kecamatan Batulappa Kabupateng Pinrang dapat dilakukan dengan memperbaiki kuantitas dan kualitas variabel harga, jumlah produksi, tenaga kerja, jumlah pohon dan untuk mencapai hasil pendapatan pengrajin gula merah di daerah lain maupun di Kelurahan Kassa Kecamatan Batulappa Kabupaten Pinrang menigkatkan pendapatan hasill tani.

\section{DAFTAR PUSTAKA}

Ariandi, 2016, Pengenalan Enzim Amilase (Alpha-Amylase) Dan Reaksi Enzimatisnya Menghidrolisis Amilosa Pati Menjadi Glukosa, Jurnal Dinamika, , halaman 74-82, Vol. 07. No. 1, ISSN 2087 - 7889

Akuba. 1993. Prospek pengembangan aren di Irian Jaya. Laporan Bulanan. Oktober 1993. Balitka Manado.

Alam S dan D Baco.2004. Peluang Pengembangan dan Pemanfaatan Tanaman Aren di Sulawesi Selatan. Pengembangan Tanaman Aren. Prosiding Seminar Nasional Aren.Tondano. Balai Penelitian Tanaman Kelapa dan Palma Lain, 9 Juni hlm.1521.

Budiarto, 2010. Faktor-faktor yang Berpengaruh Terhadap Pendapatan dan Produktivitas
Agroindustri Gula Kelapa di Kabupaten Pangandaran.

Dedi SE, 2011 Prospek Pengebangan Tanaman Aren ( Arenga Pinanta) Mendukung Kebutuhan Bioetanol di Indonesia. Pusat Penelitian dan Pengembangan. Cimanggu. Bogor. 23 April 2011.

Duryat, 2012.Manajemen Usaha Nira Aren (Arengga Pinnta) Sabagai Bahan Baku Gula Merah Dari Kawasan Taman Hutan Raya Sumber Agung Kecamatan Kemiling Kota Bandar Lampung.

Effendi, D.S. 2009. Aren, Sumber Energi Alternatif. Warta Penelitian dan Pengembangan Pertanian.Tahun 2009. 31(2):1-3.

D. $\quad$ S. 2010.Prospek pengembangan tanaman aren (Arenga pinnata Merr) mendukung kebutuhan bioetanol di Indonesia. Perspektif 9 (1):36 46.

Heyne, K,1950. Tumbuhan Berguna Indonesia.Jilid 1. Terjemahan oleh Badan Litbang kehutan,Jakarta. 615 p.

Kusnandar, T. Mardikanto dan A. Wibowo, 2010. Manajemen Agroindustri,Kajian Teori dan Model Kelembagaan Skala Kecil Pedesaan. Cetakan 1.Surakarta.UNS Press.

Lubis W, Sihombing L, Salmiah. 2008. Analisis Nilai Tambah Usaha Pengolahan Gula Aren di Desa Suka Maju Kecamatan Sibolangit Kabupaten Deli Serdang. Program Studi Agribisnis Fakultas Pertanian Universitas Sumatera Utara.

Mawardati. 2015. Analisis Faktor-faktor yang mempengaruhi pendapatan petani pinang Kecamatan Sawang Kabupaten Aceh Utara.staff pengajar fakultas pertanian Universitas Malikussaleh. Lhokseumawe. Agrisep Vol (16) No.1 2015 
Mugiono, dkk., 2014..Faktor-faktor yang Berpengaruh Terhadap Pendapatan dan Produktivitas Agroindustri Gula Kelapa di Kabupaten Pangandaran.

Ramadani P., I. Khaeruddin, A. Tjoa Dan If.Burhanuddin. 2008. Pengenalan jenis jenis pohon Yang Umum Di Sulawesi. UNTAD Press, Palu

Shafira K, Fauzia L, Iskandarini. 2011. "Analisis Kelayakan Usaha Gula Aren Studi Kasus Desa Mancang Sumatera Utara". Program Studi Agribisnis Fakultas Pertanian Sumatera Utara.

Sinunggan., 2009 .Produktivitas, apa dan bagaimana. Cetakan ketujuh. Penerbit Bumi Aksara. Jakarta.

Yuniarto, 2008.Analisis Faktor-Faktor Yang Mempengaruhi Produksi Bawang Merah Studi Kasus Desa Kendawa,Kecamatan Jatibarang Kabupaten Brebes. Universitas Diponegoro, Semarang 